\title{
Pre-service teachers' web pedagogical content knowledge and online information searching strategies
}

Güler Tuluk, İbrahim Kepceoğlu

Department of Science and Mathematics Education, Kastamonu University, Turkey

\begin{tabular}{l}
\hline \hline Article Info \\
\hline Article history: \\
Received Mar 11, 2019 \\
Revised Apr 10, 2019 \\
Accepted May 12, 2019 \\
\hline
\end{tabular}

Keywords:

Online information searching Pre-service teachers

Web pedagogical content

\begin{abstract}
This study aimed to investigate the relationship between pre-service teachers' web pedagogical content knowledge and online information searching strategies. In accordance with the aim, the correlational comparative survey method is used. The participants of the study are 220 university students from a faculty of education of a state university. The data of the study is gathered by Turkish versions of "Teachers' Self-Efficacy toward the Web Pedagogical Content Knowledge Scale" and "Online Information Searching Strategy Inventory". Canonical correlation analysis is used to determine the relationship between these two scales. As a result of the study, 17.3\% common variance is determined between web pedagogical content knowledge and online information searching strategies.
\end{abstract}

Copyright (C) 2019 Institute of Advanced Engineering and Science. All rights reserved.

\section{Corresponding Author:}

Güler Tuluk,

Department of Science and Mathematics Education,

Kastamonu University,

Kastamonu University, Faculty of Education, Kastamonu, Turkey.

Email: gtuluk@gmail.com

\section{INTRODUCTION}

Today, the daily lives of individuals are influenced by information technology, for example, using the Internet and the web. In Signorini and Gulli's evaluation, there were indexed 11.5 million web pages and it has been increasing by $8 \%$ per week [1]. This unlimited increase in web pages brought with it a number of problems related to the use of information technology. For example, it is thought that there was decline in knowledge quality and person's evaluating himself about time and environment online [2,3]. Although it is thought that there are many helpful elements on the web, it can be considered that today we face a problem of validity and reliability as well [4]. Therefore, we need to examine and reconsider search and use strategies to successfully acquire useful information on the web.

Nowadays, individuals are required have a strategy of searching qualified information for this, must be able to see the difference between known and unknown, and use cognitive processes in online information searching strategies [5]. The strategies in order to seek for information online are defined as expressing the required information interacting with the internet tools [6, 7]. In previous studies, it has been tried to determine the different information search strategies that individuals may have. Tsai and Tsai [8] evaluate individuals' information seeking strategies in behavioral, procedural, and meta-cognitive frameworks. In that study, strategies of teachers to seek for online information are included in this context. This framework has been developed on the basis of three different domains (behavioral, procedural, meta-cognitive) and seven different information search strategies covered by these domains [9].

Tsai, Liang, Hou and Tsai [10] reviewed the role of information search strategies in two different search contexts, such as searching for learning online and searching for information about everyday life and found that searching information about everyday life was significantly higher than searching for learning online. It was proposed in a study to give tasks integrated to everyday life to educators and trainers who 
benefit from information search tasks [11]. Considering the research suggests that the search for information and information processing in the online environment is a complex cognitive process involving multifaceted cognitive and supra-cognitive strategies [8] and the fact that there are pre-service teachers who use internet as the primary source of information [12] and teacher expectations to use intertet [13], we investigated the prospective pre-service teacher's internet / web usage information is before becoming a teacher.

In the study, "Online Information Search Strategy Inventory" adapted to Turkish by Aşkar and Mazman [11] developed by Tsai [9] was used. The scale was prepared as a 6-point Likert-type scale, and the answers are listed as "they never fit me" and "they completely fit me." The lowest score to be taken from the scale is 25 and the highest score is 150 . As the Internet has become accessible at anytime and anywhere, prospective teachers need to develop their skills in using web technologies in their education before becoming a teacher. Prior to these studies, Shulman [14] focuses primarily on subject area knowledge. In his subsequent work [15] he adds Pedagogical Knowledge and Pedagogical Area Knowledge to subject area knowledge. This information is different from the general pedagogical knowledge shared by specialist or interdisciplinary teachers [16]. Koehler \& Mishra [17] involve technological pedagogical field knowledge in these two areas. In the final structuring, field and teaching, pedagogy and technology components are included. In Lee and Tsai's study [4], it is stated that teachers need to know a set of web tools for a particular task, as well as which pedagogical strategies are used on the web to get the most effective results in Web Pedagogical Knowledge. Lee and Tsai [18] stated that they can not only teach content in Web Content Information but also know how to integrate content into web environment. Lee and Tsai [18] described Web Pedagogical Content Knowledge as the teaching by using web features and advantages.

Web pedagogical content knowledge can be structured as the content, the pedagogy and the web. Teacher or teacher candidates in web content knowledge not only know the content they will teach, they also know how to integrate content into web applications. Web pedagogy information includes knowledge of the Web facilities and components that teachers use in educational settings. The web pedagogical content knowledge scale [18] was developed by Lee, Tsai and Chang in 2008 and was tested by teachers with confirmatory factor analysis [18]. The scale was published as 30 items. The explanatory and confirmatory factor analysis of the Turkish version of the scale was carried out by Horzum [19]. This scale was used in the study. It must be considered that pre-service teachers' online information search strategies and the identification of web pedagogical content information are important in terms of both guiding students and reaching information and materials related to their fields. This situation is thought to be beneficial both in terms of both their own development and the quality of students' learning outcomes [20]. The purpose of this study is to associate information on search strategies and web pedagogical content knowledge of secondary school mathematics pre-service teachers who had taken courses in Instructional Technology and Material Design in their second year and Computer I and II in their first year. The resarch problem of the study is chosen as follow: "What are the pre-service teachers' web usage strategies and web pedagogical content knowledge and how are these two concepts correlated?"

\section{RESEARCH METHOD}

For the purpose of the study, the correlational research model was used. Correlational designs are research designs aimed at determining whether there is a relationship between two or more variables [21, 22].

The participants of this study consisted of 220 university students studying at Kastamonu University Faculty of Education in 2014-2015 Academic Year. For the analysis of correlations of canonical expressions to be reliable, working group can include a total of 15 to 20 times the total number of variables in the set [23]. In this research, web pedagogical content knowledge scale consists 5 variables consisting General Web (GW), Communicative Web (CW), Pedagogical Web (PW), Web Pedagogical Content (WPC) and Web Based Instructional attitude (WI) and Online Information Searching Strategy Inventory (OISSI) scale consists 7 variables; Disorientation (D), Evaluation (E), Purposeful Thinking (PT), Trial Error (TE), Select Main Ideas (SMI), Control (C) and Problem Solving (PS) and in total, there were 12 variables. Accordingly, at least 180 participants in the study group needed to be present for the reliability of the findings from canonical correlations. Therefore, it can be said that the number of participants in the study group is sufficient for the reliability of the findings obtained in this investigation.

\subsection{Instrumentation}

The Web Pedagogical Content Scale (WPCS) and the Online Information Searching Strategy Inventory (OISSI) were used as data collection tools in the study.

Web Pedagogical Content Scale (WPCS): The Web Pedagogical Content Scale was developed by Lee, Tsai and Chang in 2008 and has been tested on teachers with construct validation factor analysis [18]. This scale, which has a 5-point Likert-type rating, is published as 30 items. The explanatory and

Int. J. Eval. \& Res. Educ. Vol. 8, No. 2, June 2019: 229 - 236 
confirmatory factor analysis of the Turkish version of the scale was carried out by Horzum (2001). The scale has a five-dimensional structure consisting of General Web (GW), Communicative Web (CW), Pedagogical Web (PW), Web Pedagogical Content (WPC) and Web Based Instructional Attitude (WI).

There were 7 items in the GW section of the scale and the points that can be taken from this section ranged from 7 to 35.E.g., I can get a print-out of the website's content. There were 4 items in the CW section of the scale, and the points that could be taken from this section ranged from 4 to 20. E.g., In a chat room, I can read the messages of others. There were 5 items in the PW section of the scale, and the points that could be taken from this section ranged from 5 to 25 . E.g,. I can select appropriate content from web sources. There were 8 items in the WPC section of the scale, and the scores that could be taken from this section ranged from 8 to 40. E.g., I can choose from the available web-based courses to support teaching. There were 6 items in the WI section of the scale and the points that could be taken from this section ranged from 6 to 30 . E.g., Web-based teaching is a trend towards the future in education. The reliability of the scale was assessed by the Cronbach alpha internal consistency coefficient. As a result of the analysis, the score of the whole scale was 0.96 , and $0.94,0.96,0.94,0.95$ and 0.92 for the factors, respectively. These values are interpreted as high reliability values.

Online Information Searching Strategy Inventory (OISSI): Online Information Searching Strategy Inventory was adapted to Turkish by Aşkar and Mazman [11] and was developed by Tsai [9]. The scale was prepared as a 6-point Likert-type scale, and the answers are listed as "they never fit me" and "they completely fit me." The lowest score to be taken from the scale was 25 and the highest score was 150 . The inventory had 7 dimensions labeled as Disorientation (D), Evaluation (E), Purposeful Thinking (PT), Trial and Error (TE), Select Main Ideas (SMI), Control (C) and Problem Solving (PS).

Since the factor loadings of the measured items were not equal to each other, the McDonald coefficient, which was found to give more appropriate results for the congenerometric measurements, was also calculated and found 0.942 , while the Cronbach alpha value of the whole scale was 0.910 .

\subsection{Data analysis}

The relationship between web pedagogical content knowledge and online information search was examined by canonical correlation analysis. The canonical correlation analysis is used to examine the relationship between at two sets of variables $[(\mathrm{X} 1, \mathrm{X} 2, \ldots, \mathrm{Xn}$ and $\mathrm{Y} 1, \mathrm{Y} 2, \ldots, \mathrm{Ym})$ and (n2 and $\mathrm{m} \geq 2)$, each with at least two variables $[24,25]$.

In canonical correlation analysis, the relationship between two data sets can be demonstrated by a single analysis. In this direction, canonical correlation analysis reduces the possibility of meaningfully accepting non-meaningful relationships by keeping the Type I error which may interfere with the measurement process under control [26]. In the analysis of canonical correlation, if the dependent and independent variable sets can be distinguished theoretically between two variable sets, canonical correlation is aimed to determine whether the set of independent variables affects the dependent variable set. However, in the analysis of canonical correlation, it is not obligatory to subject two sets of variables to a separate set such as dependent and independent variables [27]. In this case, a nomenclature of Set1 and Set2 is preferred for two variable sets, and the aim of canonical correlation is to determine the relationship between Set1 and Set2 [28, 23].

In the analysis of canonical correlation, firstly the linear relationship between the two sets of variables is obtained [29-32]. The canonical variables are defined as lineer parts of new variables [33-35]. The maximum number of canonical variable pairs that can be generated in the canonical correlation analysis is equal to the number of variables in that set if there are fewer variables in the set of variables [29, 30]. The first canonical variable pair obtained in the canonical correlation analysis is calculated as the maximum relation between variable sets [33]. Then the second canonical variable pair is generated and this process is continued. The second canonical variable pair represents the maximum relation between the two canonical variables not taken into account when calculating the correlation between the first canonical variable pair [29]. The value of canonical correlation is reduced for each new function obtained between the two canonical variables [25]. In practice, only functions that are statistically significant between the two canonical variables are interpreted [31]. The general scheme of the canonical correlation analysis is shown in Figure 1. 


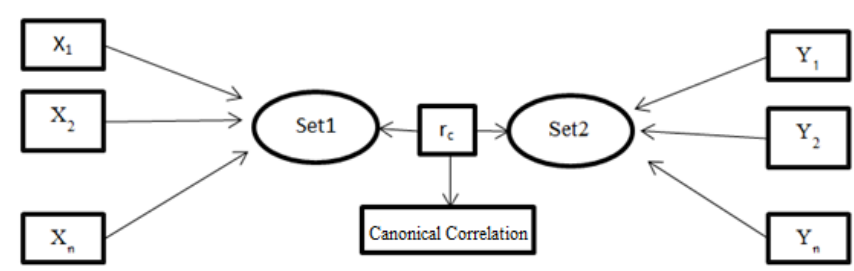

Figure1. Canonical correlation analysis

Using the canonical correlation analysis in this study, the relationship between the Web pedagogical content knowledge set consisting of weighted combinations of GW, CW, PW, WPC and WI variables and the online information search set consisting of weighted combinations of variables D, E, PT, TE, SMI was aimed to be found. In the study, there are 5 variables in the two data sets and 7 variables in the other data sets. Therefore, the maximum number of canonical variable pairs that can be generated is 5 , as shown below and cited in the manuscript.

\section{RESULT AND DISCUSSION}

In this section, findings obtained by canonical correlation analysis are included. In the analysis of canonical correlation, the results of the multivariate significance test should be examined showing the significancy of the canonical model. Those significance tests consist of four different tests called Pillais, Hotellings, Wilks and Roys. Each of these tests can be converted to a more familiar statistic, F, to test the significance of the resulting canonical model. The difference in the theoretical basis on which each of these four tests is based also leads to a different $F$ value calculated for each test. However, interpretations are based on the Wilks $\chi$ test [29], as it is generally more feasible in research as shown in the Table 1.

Table1. Test of significance of the resulting canonical model

\begin{tabular}{llllll}
\hline Test & Value & Approximate F & Hypothesis sd & Error sd & Sig. F \\
\hline Pillai & .18223 & 1.14555 & 35.00 & 1060.00 & 0.025 \\
Hotellings & .19798 & 1.16753 & 35.00 & 1032.00 & 0.023 \\
Wilks & .82709 & 1.15723 & 35.00 & 877.41 & 0.024 \\
Roys & .10817 & & & & \\
\hline
\end{tabular}

When the findings in Table 1 are examined, it is seen that the canonical model obtained from the research is statistically significant [Wilks's $\lambda=.82709, \mathrm{~F}(35,877.41)=1.15723, \mathrm{p}<.05$ ]. However, the significance of these tests does not give information about the power of the relationship. Given the fact that even small $\mathrm{F}$ values that are not significant in practice may be significant in terms of statistics in researches with high sampling, it is very important to make an assessment of the effect size as well as the significance of the model in canonical correlation analysis. In this context Wilks lambda value is used which is called reverse effect size. The Wilks $\lambda$ value expresses the unexplained variance among the canonical variables in the model obtained as the result of the analysis. Thus, "1- $\lambda$ " indicates the value of shared variance by the canonical variables and may be stated as the value of $\mathrm{R}^{2}$ in the regression. That value for Wilks's $\lambda$ value in the previous chart is calculated as .17291 . According to this, it can be said that the common variance shared between web pedagogical content knowledge and online information search sets is $17.3 \%$.

In canonical correlation analysis, the significance of each canonical function in the model needs to be examined separately, in addition to whether the canonical model obtained is statistically significant. The canonical functions resulting from the analysis are processed with the cumulative values. Therefore, it is necessary to evaluate the significance of each canonical function separately with the canonical model while interpreting the results of canonical correlation analysis. Self-values and canonical correlation values for canonical functions are examined to determine which of the canonical functions are meaningful [29]. Five canonical functions were obtained as a result of the canonical correlation analysis applied to investigate the relationship between web pedagogical content knowledge and online information search sets in the research. The eigenvalues and canonical correlation values of these functions are shown in Table 2.

Int. J. Eval. \& Res. Educ. Vol. 8, No. 2, June 2019: 229 - 236 
Table2. Eigenvalues and canonical correlation values

\begin{tabular}{cccccc}
\hline $\begin{array}{c}\text { Root } \\
\text { No }\end{array}$ & Eigenvalue & Percentage & $\begin{array}{c}\text { Cumulative } \\
\text { Percentage }\end{array}$ & $\begin{array}{c}\text { Canonical } \\
\text { Correlation }\end{array}$ & $\begin{array}{c}\text { Canonical } \\
\text { Correlation Square }\end{array}$ \\
\hline 1 & 0.12129 & 61.26282 & 61.26282 & 0.32889 & 0.10817 \\
2 & 0.04802 & 24.25456 & 85.51738 & 0.21406 & 0.04582 \\
3 & 0.01878 & 9.48614 & 95.00352 & 0.13577 & 0.01843 \\
4 & 0.00929 & 4.69112 & 99.69463 & 0.09593 & 0.00920 \\
5 & 0.00060 & 0.30537 & 100.00000 & 0.02458 & 0.00060 \\
\hline
\end{tabular}

According to the findings in Table 2, the canonical correlation value for the first canonical function is .32889. Accordingly, in the first canonical function, web pedagogical content knowledge and online information search sets share a variance of $10.817 \%$. In the second canonical correlation, the canonical correlation value, which is not taken into account in the first canonical function, and which indicates the maximum relation between the two canonical variables is calculated. The calculated value for the second canonical function is .21406 , according to which web pedagogical content knowledge and online information search data sets share a variance of $4.582 \%$ in the second canonical function. The calculated value for the third canonical function is .13577 , where web pedagogical content knowledge and online information search data sets share a variance of $1.843 \%$ in the third canonical function. The calculated value for the fourth canonical function is .09593 , according to which web pedagogical content knowledge and online information search data sets share a variance of $0.92 \%$ in the fourth canonical function. The canonical correlation value of the fifth canonical function appears to be .02458 after subtraction of the common variance of the web pedagogical content knowledge and the online information search data sets in the first four canonical functions. Accordingly, the web pedagogical content knowledge for the fifth canonical function and the common variance shared by the online information search data sets are only $0.06 \%$.

Separate examination of the significance of each canonical function in canonical correlation analysis sheds light on the need to interpret the functions resulting from canonical correlation analysis. Tabachnick and Fidell [34] stated that only statistically significant canonical functions should be interpreted in canonical correlation analysis. Generally, the correlation between canonical variables for the last canonical function is not statistically significant [36]. The results of the dimension reduction analysis of the relationship between web pedagogical content knowledge and online information search sets are shown in Table 3.

Table3. Results of dimension reduction analysis

\begin{tabular}{cccccc}
\hline Roots & Wilks L. & F & Hypothesis Sd & Error Sd & Sig. F \\
\hline 1 TO 5 & 0.82709 & 1.15723 & 35 & 877.41 & 0.024 \\
2 TO 5 & 0.92741 & 0.66449 & 24 & 730.32 & 0.088 \\
3 TO 5 & 0.97195 & 0.40072 & 15 & 580.12 & 0.097 \\
4 TO 5 & 0.9902 & 0.26041 & 8 & 422 & 0.097 \\
5 TO 5 & 0.9994 & 0.04272 & 3 & 212 & 0.098 \\
\hline
\end{tabular}

According to the findings in Table 3, the canonical model (function 1 to 5) consisting of the added values of the five canoniqal functions is statistically significant $[\lambda=.82709, \mathrm{~F}(35,877.41)=1.15723, \mathrm{p}$ $<.05]$. There is no statistically significant relationship between web-based pedagogical content knowledge and online information search data sets for other canonical functions (function 2) after theremoval of the first canonical function with the highest correlation between canonical variables [p> .05].

Another question to be answered in canonical correlation analysis is how the variables in the data sets contribute to the relationship between the canonical variables. Standardized coefficients and structural coefficients of canonical functions are used to answer this question. In this study, to determine the contribution of GW, CW, PW, WPC and WI variables in the web pedagogical content knowledge set and D, E, PT, TE, SMA, C and PS variables in the online information search set to canonical variables, standardized coefficients and structural coefficients of the first function between variables are investigated. The findings are shown in Table 4. 
Table4. Standarized coefficients and structural coefficents

\begin{tabular}{llll}
\hline & \multicolumn{3}{l}{ 1. Canonical Function } \\
\hline Variable & SEK & $\mathrm{r}_{\mathrm{s}}$ & $\mathrm{r}_{\mathrm{s}}^{2}(\%)$ \\
GW & 0.593 & 0.631 & 0.398 \\
CW & -0.352 & 0.074 & 0.005 \\
PW & 0.771 & 0.502 & 0.252 \\
WPC & 0.089 & 0.360 & 0.129 \\
WI & 0.378 & 0.584 & 0.341 \\
D & -0.425 & 0.112 & 0.012 \\
E & 0.179 & 0.334 & 0.111 \\
PT & -0.684 & 0.026 & 0.001 \\
TE & -0.029 & 0.367 & 0.134 \\
SMA & 0.291 & 0.814 & 0.662 \\
C & -0.217 & 0.369 & 0.136 \\
PS & 0.201 & 0.322 & 0.103 \\
\hline
\end{tabular}

The canonical correlation coefficient between the structural coefficients for the first canonical function and the web pedagogical content knowledge for this function and the online information search data sets is also shown in Figure 2.

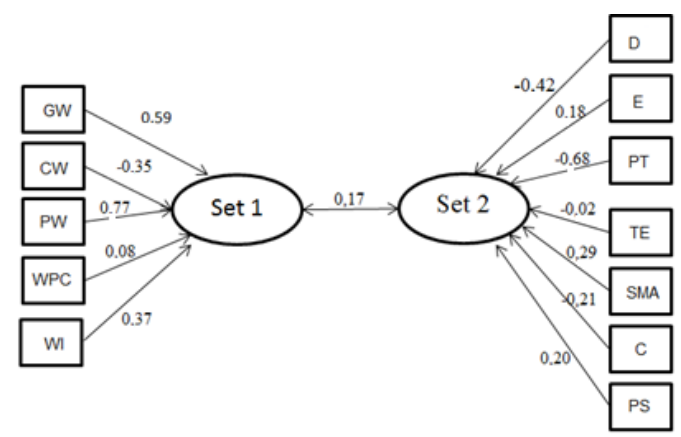

Figure2. The canonical correlation coefficient between the structural coefficients for the first canonical function and the web pedagogical content knowledge

This study aimed to investigate the relationship between pre-service teachers' web pedagogical content knowledge and online information searching strategies. Canonical correlation analysis is used to determine the relationship between these two scales. As a result of the study, $17.3 \%$ common variance is determined between web pedagogical content knowledge and online information searching strategies.

In the educational context, students use wikis, videos, blogs, e-books, social networks, simulations and 3-D virtual learning environments via web pages $[11,37]$ while they use the internet for their projects. However, among these sources; content, objectivity, accuracy, timeliness, and target audience [38] presented in these sources [39]. This is important for teachers to use the internet effectively in the teaching-learning process, to follow innovations in the field of education [40], and to have a particularly qualified literacy of their students [41]. As a matter of fact, the researches show that while students search for information on the internet [20], they encounter problems in using search engines, determining keywords in online information search, and not evaluating search results [42, 39]. In this case, we have to observe the content of EMB203 Teaching Technology and Material Use lesson that the teacher candidates are trained in before the service. While technology creates more tools for the use of teachers and students, in-service teacher education should fulfill its responsibilities to educate teachers who use these tools properly.

While education combines learning with computer based electronic technologies, it has to be related to the subject area of these technologies $[37,41,43]$. It is thought that this study, which we want to capture the viewpoint of the mathematics teacher candidate, will allow us to investigate what is and what is required of the field knowledge, the teaching of the field knowledge, and the technological pedagogical field knowledge.

Int. J. Eval. \& Res. Educ. Vol. 8, No. 2, June 2019: 229 - 236 


\section{CONCLUSION}

It is necessary to integrate education and training with technology so that learning-teaching processes can bring about a more effective and productive success, as seen in education systems. Classical learning methods can be replaced by new learning methods supported by technology and web. Considering the web pedagogical content information provided by the combination of education and technology, web pedagogical content information is also increasing in the case of increasing internet usage among students. For this reason, as a result of being able to carry out the researches of the teacher candidates easily and to improve themselves in the field of field and vocational knowledge, it may be necessary to educate the teacher candidates about this achievement and to educate them in this field in order to ensure success in education and universality. This may require that the classes and laboratories of the education faculties are improved technologically or if they are completely renewed if necessary and that the web technology is used without problems and that there is an internet connection that is free of obstacles or wireless and that there is a meaningful relationship between web pedagogical content knowledge and teacher self-efficacy perception. It can be said that the teacher candidates tend to forget the self-efficacy of the teacher in case the web pedagogical content information is touched. Teacher candidates use the information of the pedagogical content in their education and training can be considered as an increase in quality and efficiency in the student generation. Technology, pedagogy and content knowledge as a whole and the education system can be restructured accordingly.

\section{REFERENCES}

[1] X Ntoulas, A., Cho, J., \& Olston, C., "What's new on the web? The evolution of the web from a search engine perspective," In Proceedings of the 13th international World Wide Web Conference (pp. 1-12), New York, 2004

[2] Ahuja, J. S., \& Webster, J. "Perceived disorientation: An examination of a new measure to assess web design effectiveness," Interacting with Computers, vol. 14, pp. 15-29, 2001.

[3] Rockland, R. H., "Reducing the information overload: A method on helping students research engineering topics using the Internet," IEEE Transactions on Education, vol. 43, pp. 420-425, 2000.

[4] Tsai, C-C., "The interpretation construction design model for teaching science and its applications to Internet-based instruction in Taiwan," International Journal of Educational Development, vol. 21(5), pp. 401-15, 2001.

[5] Tabatabai, D, \& Shore, B. M, "How experts and novices search the Web," Library \& information science research, vol. 27(2), pp. 222-248, 2005.

[6] Belkin, N. J., Cool, C., Stein, A., \& Thiel, U., "Cases, scripts, and information-seeking strategies: On the design of interactive information retrieval systems," Expert systems with applications, vol. 9(3), pp. 379-395, 1995.

[7] Bilal, D., "Children's use of the Yahooligans! Web search engine. I. Cognitive, Physical and affective behaviors on fact-based tasks," Journal of the American Society for Information Science, vol. 51, 646-665, 2000.

[8] Tsai, M. J., \& Tsai, C. C, "Information searching strategies in web-based science learning: The role of Internet selfefficacy," Innovations in education and Teaching International, vol. 40(1), pp. 43-50, 2003.

[9] Tsai, M.J., "Online Information Searching Strategy Inventory (OISSI): A quick version and a complete version," Computers \& Education, vol. 53, pp. 473-483, 2009.

[10] Tsai, M. J., Liang, J. C., Hou, H. T., \& Tsai, C. C., "University students' online information searching strategies in different search contexts," Australasian Journal of Educational Technology, vol. 28(5), 2012.

[11] Aşkar, P., \& Mazman, S. G, "Çevrimiçi bilgi arama stratejileri envanterinin Türkçe’ye uyarlama çalışması," Eğitim ve Bilim, vol. 38(168), 2013.

[12] Lorenzen, M., "The land of confusion? High school students and their use of the World Wide Web for research," Research Strategies, vol. 18(2), pp. 151, 2002.

[13] Ministry of National Education (MoNE), Ortaöğretim matematik dersi öğretim programı. Ankara: Milli Ĕgitim Basımevi, 2015.

[14] Shulman, L. S., "Those who understand: Knowledge growth in teaching," Educational researcher, vol. 15(2), pp. 4-14, 1986.

[15] Shulman, L., "Knowledge and teaching: Foundations of the new reform," Harvard educational review, vol. 57(1), pp. 1-23, 1987.

[16] Koehler, M. J., Mishra, P, \& Yahya, K., "Tracing the development of teacher knowledge in a design seminar: Integrating content, pedagogy and technology," Computers \& Education, vol. 49(3), pp. 740-762, 2007.

[17] Koehler, M. J, \& Mishra, P, "What happens when teachers design educational technology? The development of technological pedagogical content knowledge," Journal of educational computing research, vol. 32(2), pp. 131-152, 2005.

[18] Lee, M. H, \& Tsai, C. C, "Exploring teachers' perceived self efficacy and technological pedagogical content knowledge with respect to educational use of the World Wide Web," Instructional Science, vol. 38(1), pp. 1-21, 2010

[19] Horzum, M. B., "Adaptation of web pedagogical content knowledge survey to Turkish," Elementary Education Online, vol. 10(1), pp. 257-272, 2011

[20] Bilal, D., \& Kirby, J, "Differences and similarities in information seeking: children and adults as web users," Information Processing and Management, vol. 38, pp. 649-670, 2002

[21] Karasar, N., Bilimsel araştırma yöntemi: kavramlar, ilkeler, teknikler, Nobel Yayın Dağıtım, 2009.

Relationship between pre-service teachers' web pedagogical content knowledge... (Güler Tuluk) 
[22] Erkuş, A., Davranış bilimleri için bilimsel araştırma süreci, Seçkin Yayıncılık, 2011.

[23] Stevens, J. P., Applied multivariate statistics for the social sciences, New York: Routledge, 2009.

[24] Varmuza, K. \& Filzmoser, P, Introdurction to multivariate statistical analysis in chemometrics. Boca Raton: CRC Press, 2009.

[25] Bordens, K. S. \& Abbott, B. B, Research design and methods: A process approach. New York: The McGraw-Hill Companies, 2011.

[26] Stangor, C., Research methods for the behavioral sciences, Wadsworth, 2010.

[27] Albayrak, A. S., Kanonik korelasyon analizi. SPSS uygulamalı çok değişkenli istatistik teknikleri. (Edt: Ş. Kalaycı). Ankara: Asil Yayın Dağıtım. ss. 234-255, 2010.

[28] Pedhazur, E. J., Multiple regressions in behavioral research: Explanation and prediction, New York: Holt, Rinehart \& Winston, 1997.

[29] Fan, X., "Canonical correlation analysis and structural equation modeling: What do they have in common? Structural Equation Modeling," vol. 4, pp. 65-79, 1997.

[30] Henson, R. K., "Demystifying parametric analyses: Illustrating canonical correlation as the multivariate general linear model," Multiple Linear Regression Viewpoints, vol. 26 (1), pp. 11-19, 2000.

[31] Leech, N. L. Barlett, K. C, \& Morgan, G. A., SPSS for intermediate statistics; Use and interpretation, Mahwah, NJ: Lawrence Erlbaum Associates, 2005.

[32] Everitt, B. \& Hothorn, T, An introduction to applied multivariate analysis with R, New York: Springer, 2011.

[33] Afifi, A. \& Clark, V, "Computer-aided multivariate analysis," Boca Raton, Fl: Chapman \& Hall/CRC, 2004.

[34] Tabachnick, B. G. \& Fidell, L. S, Using multivariate statistics. Boston, Pearson Education, Inc, 2007.

[35] Hair, J. F, Black, W. C, Babin, B. J, \& Anderson, R. E., Multivariate data analysis. Englewood Cliffs, New Jersey: Prentice Hall, 2010.

[36] Sherry, A. \& Henson, R.K, "Conducting and interpreting canonical correlation analysis in personality research: A user-friendly primer," Journal of Personality Assessment, vol. 84 (1), pp. 37-48, 2005.

[37] Ersoy, A., \& Türkkan, B, "İlköğretim öğrencilerinin resimlerinde internet algısı," İlköğretim Online, vol. 8(1), 2009.

[38] Beaufils, A., "Tools and strategies for searching in a hypermedia environment," Journal of Computer Assisted Learning, vol. 16, pp. 114-124, 2000.

[39] Bilal, D., "Children's use of the Yahooligans! Web search engine. II. Cognitive, Physical and affective behaviors on fact-based tasks," Journal of the American Society for Information Science, vol. 52, pp. 118-137, 2001.

[40] Braten, I., \& Stromso, H. I, "Epistemological beliefs, interest, and gender as predictors of internet-based learning activities," Computers in Human Behavior, vol. 22, pp. 1027-1042, 2006.

[41] Chan, C. K. K., \& Sachs, J, "Beliefs about learning in children's understanding of science texts," Contemporary Educational Psychology, vol. 26, pp. 192-210, 2001.

[42] Duell, O. K., \& Schommer-Aikins, M, "Measures of people's beliefs about knowledge and learning," Educational Psychology Review, vol. 13, pp. 419-449, 2001.

[43] Lee, MH., Tsai, CC. ve Chang, CY., "Exploring Teachers' Self-Efficacy toward the Web Pedagogical Content Knowledge in Taiwan," Paper presented at the Annual Meeting of the American Educational Research Association New York City, Mar 24-28, 2008, 2008.

Int. J. Eval. \& Res. Educ. Vol. 8, No. 2, June 2019: 229 - 236 